Rev. Elev. Méd. vét. Pays trop., 1970, 23 (1) . 1-13

\title{
Recherches sur le diagnostic expérimental de la peste porcine classique par la méthode d'exaltation du virus de Newcastle
}

\author{
par J. RAMISSE, H. SERRES, E. RAKOTONDRAMARY \\ Collaboration technique : H. RAMAMBAZAFY, R. RANDRIAMAMPIANINA, J. TOTOASY
}

\begin{abstract}
RESUME
Les auteurs étudient divers facteurs conditionnant la mise en évidence du virus sui-pestique par la méthode d'exaltation du virus de Newcastle, en culture cellulaire (test E.N.D.). Ils ont retenu comme milieu d'entretien des cellules, celui de SCHWÖBEL enrichi avec du sérum de mouton (10 p. 100). La souche sui-pestique d'épreuve et les souches virulentes locales donnent un résultat positif. Les deux souches lapinisées étudiées donnent un résultat négatif. La rotation des tubes inoculés accélère le processus cyto-pathogène. La plupart des souches Newcastle utilisées comme virus révélateur conviennent. La gamme de dilutions du virus révélateur peut être relativernent étendue. Certaines suspensions tissulaires trop concentrées lysent les cellules. Il est possible d'inoculer le matériel suspect avant que la nappe cellulaire soit complète. Mais l'inoculation le jour de la mise en culture peut lyser les cellules, ou retarder leur développement.
\end{abstract}

Parmi toutes les techniques utilisées dans le diagnostic au Laboratoire de la peste porcine, nous avons étudié plus particulièrement celle inventée par KUMAGAI et coll. en 1958 (4). Cette technique est basée sur l'exaltation de l'effet cytopathogène du virus de Newcastle par le virus sui-pestique, en culture de cellules testiculaires de porc. On la désigne couramment par les initiales E.N.D. (Exaltation of Newcastle Disease virus $=$ Exaltation du virus de la maladie de Newcastle). Le principe de la technique est le suivant : le virus sui-pestique cultive sur cellules testiculaires du porc, mais sans provoquer d'effet cytopathogène. Le virus de Newcastle, sous certaines conditions, n'est pas, lui non plus, cytopathogène pour ces mêmes cellules. Mais il le devient pour des cellules testiculaires de porc préalablement infectées de virus sui-pestique. Ainsi le virus de Newcastle sert de révélateur pour ce dernier.
Le test E.N.D. a fait l'objet d'un certain nombre de publications: KUMAGAI et coll. (1961) (5) ont décrit en détail la technique. LOAN (1963) (7) a conclu que le meilleur sérum à utiliser dans ce test était celui de chèvre. KUMAGAI et coll. (1964) (6) ont amélioré la technique en augmentant la proportion de sérum entrant dans la réaction. LOAN (1965) (8) a précisé certaines modalités du test: intervalle optimal entre l'inoculation du virus sui-pestique et la surinfection avec le virus de Newcastle. De plus, il a montré que certaines souches sui-pestiques peu virulentes ou lapinisées ne donnaient pas de résultat positif. BOOL et RESSANG (1966) (1) ont montré que le test était négatif avec les souches lapinisées, sauf avec la souche IFFA passée sur cellules rénales de lapin. Ils ont établi également que l'on pouvait intervertir l'ordre des inoculations sui-pestique et Newcastle. KAA- 
DEN (1967) (2) a prétendu que ce test ne convenait pas parfaitement pour les examens de routine, car il serait, selon lui, peu sensible et difficile à réaliser lorsqu'on ne dispose pas de sérum de veau adéquat. Modifiant un peu le test E.N.D., KUBIN (1962) (3) a obtenu des résultats similaires en remplaçant le virus de Newcastle par le virus de Teschen comme agent révélateur.

De Ia lecture de ces publications, il ressort quelques constatations :

- Le test E.N.D. n'est pas simple.

- Il est assez long.

- Le maintien en bon état des cellules témoins tout au long du test exige des conditions de culture particulières. Les auteurs ont insisté notamment sur la nature et la quantité du sérum complémentant le milieu.

- Les souches lapinisées et les souches peu virulentes donnent des résultats variables.

Voulant nous rendre compte si le test E.N.D. pourrait nous être utile, à Madagascar, pour le diagnostic au laboratoire de la peste porcine, nous avons étudié quelques facteurs conditionnant sa bonne exécution. Nous avons pu ainsi mettre en évidence l'effet bénéfique du sérum de mouton et du milieu de SCHWÖBEL.

Nous décrirons succinctement les techniques employées avant d'exposer les résultats que nous avons obtenus.

\section{MATERIEL ET METHODES}

Les cultures cellulaires sont faites à partir de testicules de porcelets de 3 semaines à 1 mois. 11 n'y a aucune importance à ce que les porcelets soient issus de mères vaccinées contre la peste avec un vaccin vivant. La technique de mise en culture est identique à celle relatée par les auteurs précédemment cités. Afin de déterminer les meilleures conditions pour la réussite de la réaction, nous avons étudié différents milieux de culture :

- pour la multiplication des cellules;

- pour la replication du virus sui-pestique;

- pour la manifestation de l'effet cytopathogène du virus de Newcastle.
D'autre part, nous avons précisé :

- l'influence de la rotation des tubes inoculés;

- l'effet cytotoxique des suspensions tissulaires trop concentrées;

- l'influence du mode d'inoculation des deux virus;

- l'influence de la nature des souches virales;

- les limites d'action des virus révélateurs.

\section{Choix des milieux de culture}

\section{a) Milieux de culture}

pour la multiplication cellulaire

- Milieu de base : Il est absolument impératif pour la réussite du test que les cellules soient en excellent état. Ceci implique que le milieu de multiplication cellulaire convienne parfaitement. Les milieux suivants ont donc été essayés: Hydrolysat de lactalbumine à 0,5 p. 100 en solution de EARLE, en solution de HANKS contenant 0,1 p. 100 d'extrait de levure, Hydrolysat de caséine à 0,5 p. 1.000 en solution de EARLE contenant des vitamines B (milieu de LEPINE) (*), milieu 199 de PARKER et MORGAN, milieux BEM et MEM de EAGLE.

- Sérum complémentant le milieu: L'adjonction de sérum animal au milieu de base est indispensable pour la culture des cellules testiculaires de porc. Plus ia concentration en est élevée, plus la multiplication est rapide, et meilleur est l'aspect des cellules. Le sérum le plus couramment utilisé à ce stade de la réaction est celui de veau. Mais ce sérum est parfois inhibiteur pour le virus sui-pestique, ce qui oblige à l'éliminer au $2^{\mathrm{c}}$ stade de la réaction (replication du virus sui-pestique), ou bien à sélectionner des lots de sérum convenables. Outre le sérum de veau, nous avons essayé celui de mouton, de porc et le lait écrémé. Les concentrations étaient de 10 ou 20 p. 100. Nos sérums de veau et de mouton sont des mélanges de sérums de plusieurs sujets abattus le même jour. Les veaux à partir desquels est recueilli le sérum sont âgés de six mois environ, car à Madagascar, on n'abat pas de veaux de lait. Quant aux moutons, il s'agit d'animaux adultes.

(*) Milieu de LEPINE: Ann. Inst. Pasteur 1957, 92, $567-575$. 
b) Milieux de culture pour l'entretien des cellules pendant la replication du virus sui-pestique

- Milieux de base: Nous avons essayé le milieu 199 ajusté au $\mathrm{pH}$ 7,5, le milieu BEM de EAGLE, le milieu de LEPINE, le milieu à l'hydrolysat de lactalbumine en solution de HANKS et enfin un milieu spécial de SCHWÖB'EL.

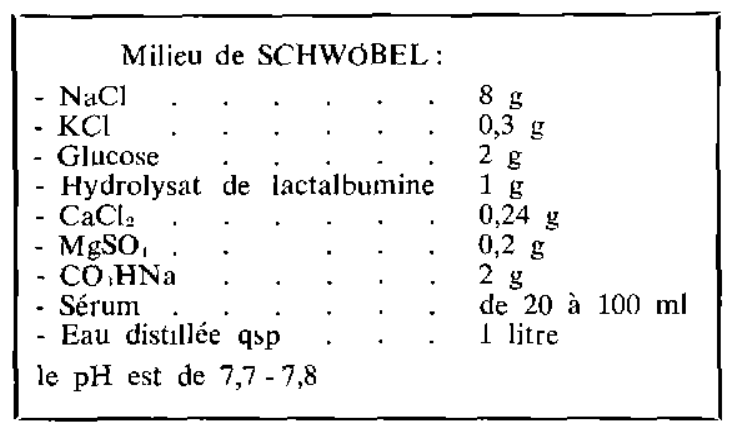

- Sérums : A ce stade il est nécessaire de ne pas employer de sérum inhibiteur pour le virus sui-pestique. Si pour la multiplication cellulaire il a été utilisé du sérum de veau ınhibiteur, il faut rincer soigneusement les cellules avant de les inoculer. Au stade de la replication du virus sui-pestique, nous avons expérimenté aux concentrations de 5,10 et 20 p. 100 , les sérums de veau local et importé, de fretus bovin, de poulain, de lapin, de poule, de porc, de mouton, ainsi que le liquide amniotique bovin et le lait écrémé.

c) Milieux de culture pour l'entretien des cellules pendant la replication du virus de Newcastle

- Milieu de base: A ce stade, les cellules sont déjà âgées. Si le milieu n'est pas étroitement adapté, il risque de se produire une dégénérescence cellulaire non spécifique. Nous avons testé successivement: Ie milieu de LEPINE avec ou sans extrait de levure, le milieu 199, le BEM de EAGLE, l'hydrolysat de lactalbumine en solution de EARLE ou HANKS, enfin le milieu de SCHWÖBEL.

- Sérums : KUMAGAI (6) et KUBIN (3) ont affirmé qu'il fallait à ce stade augmenter la concentration de sérum pour éviter la lyse des cellules par le virus de Newcastle seul. C'est pourquoi nous avons expérimenté le sérum de veau aux concentrations de 10 et 20 p. 100. En outre le sérum de mouton a été essayé.

\section{Chronologie des manipulations}

Le tapis cellulaire est complet habituellement trois jours après la mise en culture. Dans la technique classique c'est à ce moment-là que l'on inocule le virus sui-pestique (ou le prélèvement suspect).

\section{Inoculation du virus sui-pestique}

L'inoculum est constitué d'un broyat tissulaire frais ou lyophilisé, de sérum, ou de sang hémolysé. Comme organe nous utilisons le plus souvent la rate, les ganglions, le cerveau. La suspension tissulaire est à 10 p. 100 (à 2 p. 100 pour les ganglions), le volume inoculé est de 0,5 à $1 \mathrm{ml}$ par tube. Il est préférable de préparer la suspension à inoculer avec du milieu d'entretien comportant du sérum de mouton (non inhibiteur), plutôt qu'avec une solution physiologique, car les cellules résistent mieux. Les cellules sont lavées avant l'inoculation si elles ont été cultivées en présence de sérum de veau, mais elles ne le sont pas après l'adsorption du virus infectant ( 2 heures à la température du laboratoire). Le milieu d'entretien n'est renouvelé qu'une fois, deux jours après l'inoculation. Les souches sui-pestiques testées proviennent de prélèvements pour diagnostic expédiés sous glace ou en glycérine à 50 p. 100 ou d'organes et sérums virulents conservés congelés ou lyophilisés.

\section{Inoculation du virus révélateur (surinfection)}

Habitueliement, quatre jours après la primoinoculation, nous surinfectons les cellules avec le virus de Newcastle ou de Teschen. Ces virus sont dilués dans du milieu d'entretien contenant du sérum de veau et de telle façon qu'ils ne provoquent pas, seuls, de lyse cellulaire. Le virus de Newcastie est constitué de liquide allantoïdien virulent. Le virus de Teschen est utilisé sous forme de culture cellulaire infectée. L'adsorption étant faite, l'inoculum est rejeté et les cellules reçoivent le milieu d'entretien. Les tubes placés en position fixe ou sur tambours tournants sont examinés à partir du $2^{\mathrm{e}}$ jour.

\section{Nécessité de laisser des tubes témoins}

Pour que le test soit concluant et indiscutable, il faut que les cellules conservent leur intégrité dans les différents tubes témoins négatifs: une série inoculée avec la suspension à tester, mais ne recevant pas le virus révélateur, une série inoculée avec une suspension tissu- 


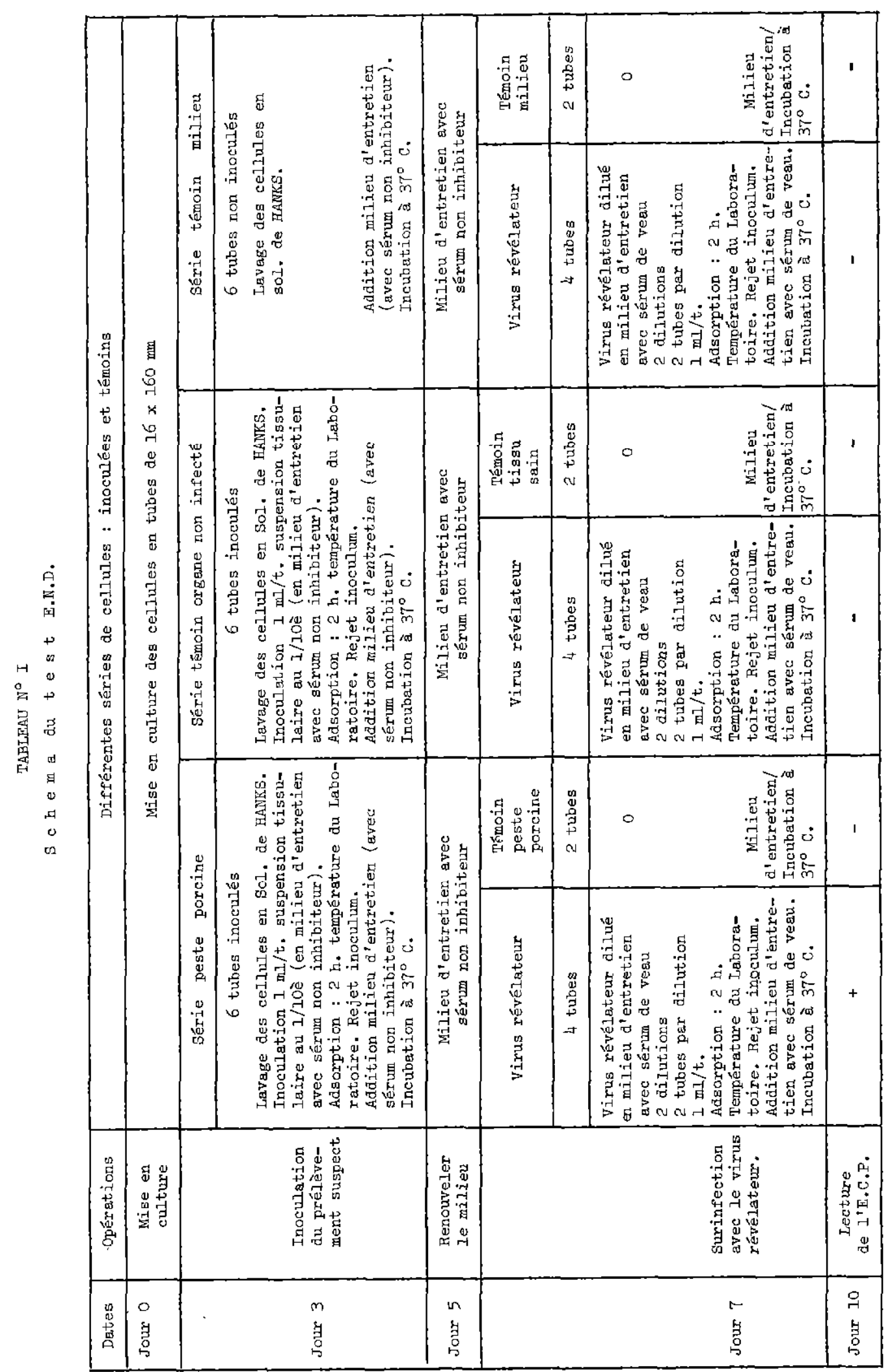


laire normale dont une partie reçoit le virus révélateur, et l'autre partie n'en reçoit pas. En outre, il est bon d'ajouter une série correspondant à un témoin connu et positif où les cellules devront être lysées au moment de la lecture.

Le résumé des manipulations est présenté dans le tableau $n^{\circ} l$.

\section{Etude des différents paramètres de la réaction}

\section{a) Gamme des dilutions actives des virus}

La gamme peut varier seion les échantillons de virus :

Pour le virus sui-pestique, la virulence sera appréciée par la dilution limite entraînant la positivité du test. Les suspensions à tester ont été diluées jusqu'à $10^{-\bar{\top}}$. A l'aide de cette méthode nous avons évalué la conservation du virus au congélateur (rates et sérums congelés depuis des temps variables) ou après lyophilisation.

Pour les virus révélateurs, nous désirions connaître les dilutions optimales donnant une réponse positive et laissant intactes les cellules témoins. Pour cela, les virus révélateurs (liquide allantoïdien ou culture cellulaire infectés) ont été dilués de $10^{-1}$ à $10^{-10}$ et inoculés à des cellules primo-infectées et non infectées. Ceci devait permettre de voir quelle serait la dilution limite encore active, et jusqu'à quelle dilution le virus révélateur seul risquait d'être cytopathogène. Ainsi donc, compte tenu du titre des virus, déterminé sur cellules ou sur embryon de poulet, pourrionsnous préciser la gamme utilisable, exprimée en dilutions ou en $\mathrm{DL}_{\bar{\imath} 0}$ ou $\mathrm{DICT}_{\overline{\mathrm{u}} \hat{0}}$.

\section{b) Ordre d'inoculation des deux virus}

Nous avons essayé de modifier la chronologie du test classique :

- en inoculant le virus sui-pestique le lendemain de la mise en culture $(1 \mathrm{ml}$ de suspension au $1 / 100$ ), et le virus de Newcastle, deux jours plus tard, lorsque la nappe cellulaire est complète. L'observation dure au moins six jours;

- en inoculant le virus sui-pestique et le virus de Newcastle simultanément, au moment où la nappe est complète. Le virus sui-pestique est dilué dans la suspension de virus de New- castle. Les tubes inoculés sont observés au moins pendant six jours;

- en inoculant le virus de Newcastle le jour de la mise en culture et le virus suipestique dès que la nappe est complète, en général trois jours plus tard.

\section{c) Influence de la rotation des tubes} après la surinfection

Voulant nous rendre compte si la rotation des tubes après la surinfection entraînait une lyse plus rapide, nous avons comparé plusieurs séries de cultures cellulaires inoculées et surinfectées, les unes laissées en position fixe (tubes sur portoirs), les autres mises en rotation sur tambour tournant. L'incubation s'est faite à $37^{\circ}$ pour toutes les séries. Nous avons observé quotidiennement tous les tubes à partir du $2^{\mathrm{e}}$ jour suivant la surinfection.

\section{d) Effet cytotoxique des suspensions d'organes}

Dans le but de savoir à quelle concentration les suspensions organiques provoquent la dégénérescence des cellules, nous avons inoculé à des cultures de cellules testiculaires, des suspensions centrifugées de rate, ganglion, cerveau, rein, pancréas, à raison de $1 \mathrm{ml}$ par tube. La concentration tissulaire de ces suspensions allait de $1 / 5$ à $1 / 80$. Les tubes ont été portés à l'étuve pendant 4 jours au cours desquels nous avons noté l'apparition éventuelle d'une dégénérescence cellulaire. Puis les cultures non dégénérées ont été infectées de virus de Newcastle (dilution $10^{-4}$ ) et incubées encore pendant 4 jours. L'observation terminale devait permettre de connaître la concentration tissulaire maximale que pouvaient supporter les cellules au cours de la réaction.

e) Influence de la nature des souches virales sui-pestiques et Newcastle

\section{Sui-pestiques}

Ayant abordé l'étude du test E.N.D. avec la souche virulente d'épreuve (A.L.D.) conservće sous forme congelée ou lyophilisée, nous avons poursuivi en utilisant les souches locales isolées de cas de peste porcine naturelle. Ces souches apparaissent moins virulentes que la souche d'épreuve et provoquent une maladie souvent subaiguë, évoluant en 10 ou 15 jours. Les lésions constatées sont assez typiques: pétéchies sur les reins, la vessie, le larynx, ganglions hémorragiques, ulcères du cæcum, hématomes de la rate. Il était évidemment 
important du point de vue diagnostic de savoir si les souches locales, moyennement virulentes, donnaient un résultat positif avec ce test.

D'autre part, et toujours sur le plan du diagnostic, il fallait se rendre compte si la souche vaccinale lapinisée (*) pouvait rendre le test positif. Ce qui aurait perturbé les résultats du diagnostic dans le cas de porcs vaccinés.

Pour préciser l'effet de la souche vaccinale, nous avons inoculé aux cellules testiculaires:

- soit un broyat de rate de lapin contenant le virus lapinisé,

- soit des broyats de rates de porcs vaccinés avec le virus lapinisé depuis $2,4,6$, 8,10 et 12 jours,

- et en outre, à titre de comparaison, la souche vaccinale IFFA adaptée aux cellules rénales de lapin, ainsi que cette même souche passée sur porc (broyat de rate de porc vacciné depuis $4,6,8$, 12 jours).

Ces cellules ont été ultérieurement surinfectées avec le virus révélateur.

\section{Virus de Newcastle surinfectant}

Pour savoir si toutes les souches de virus de Newcastle convenaient pour le test, nous avons utilisé une souche vaccinale vivante atténuée, et des souches sauvages isolées de cas de maladie naturelle. Ces souches ont été inoculées sous forme de liquide allantoïdien infecté, titré et dilué dans le milieu d'entretien des cellules testiculaires. Neuf souches ont été ainsi examinées: une vaccinale (Pakistanaise) et huit sauvages pathogènes (Malgache, D 425, D 515, Maurice, Ambatolampy, Toulouse, Perdrix, Pakistan).

\section{RESULTATS}

\section{Activation des virus révélateurs par le virus sui-pestique}

\section{Activation spécifique du virus de Newcastle}

Le virus sui-pestique seul n'exerce aucun effet cytopathogène sur les cellules testiculaires de porc. Le virus de Newcastle de même, sous certaines conditions (milieu convenable et dilu-

(*) Souche SFA de HUDSON. Nous remercions notre confrère LARENAUDIE, du L.N.R.V. de nous avoir procuré cette souche. tion suffisante), n'est pas non plus cytopathogène. Par contre, dans notre expérimentation, les cultures cellulaires inoculées depuis 4 jours avec le virus sui-pestique et surinfectées avec le virus de Newcastle (dilution 10-4), présentent à partir du $3^{\mathrm{e}}$ jour suivant la surinfection quelques zones de lyse cellulaire. A ces endroits, les cellules sont rétractées en amas grisâtres et granuleux. Leur cytoplasme est condensé et s'effiloche. En 24 heures, les trous dans la nappe s'agrandissent et il se constitue des îlots cellulaires demeurant fixés au verre, et entre lesquels subsistent des ponts cytoplasmiques. La destruction cellulaire peut être complète en 48 heures. Mais parfois persistent quelques amas de cellules plus ou moins résistantes à la lyse. A l'examen des lamelles colorées à l'hématéine-éosine, les cellules en voie de lyse ont un aspect fibroblastique avec un cytoplasme filamenteux, granuleux, et qui s'effiloche en dentelle. Il y a d'assez nombreux plasmodes multinucléés. Au centre du cercle formé par les noyaux apparaît une inclusion cytoplasmique acidophile très nette. Cette même inclusion, plus petite, se retrouve, entourée d'un halo clair dans un certain nombre de cellules en voie de lyse. Si l'on fait adsorber sur les cellules doublement infectées, des hématies de poule, celles-ci se fixent sur les amas cellulaires non détachés du verre et contenant du virus de Newcastle. Ceci prouve que la lyse est bien due au développement du virus de Newcastle.

La photo $\mathrm{n}^{0} 1$ montre une culture de cellules testiculaires témoins (fixation au Bouin, coloration à l'hématéine-éosine).

Les photos $n^{\text {nts }} 2$ et 3 présentent les images de l'effet cytopathogène dû à la double infection cellulaire, et de l'hémadsorption des hématies de poule.

\section{Activation spécifique du virus de Teschen}

Pour les cellules testiculaires de porc, dans certaines conditions de culture (milieux convenables, dilution suffisante), le virus de Teschen n'est pas cytopathogène. Mais si les cellules sont préalablement infectées de virus suipestique, l'effet cytopathogène spécifique du virus de Teschen se manifeste à partir du $3^{\mathrm{t}}$ jour suivant la surinfection. Un certain nombre de cellules s'arrondissent et se rétractent, ou bien prennent une forme en fuseau et deviennent beaucoup plus réfringentes. Des trous se 


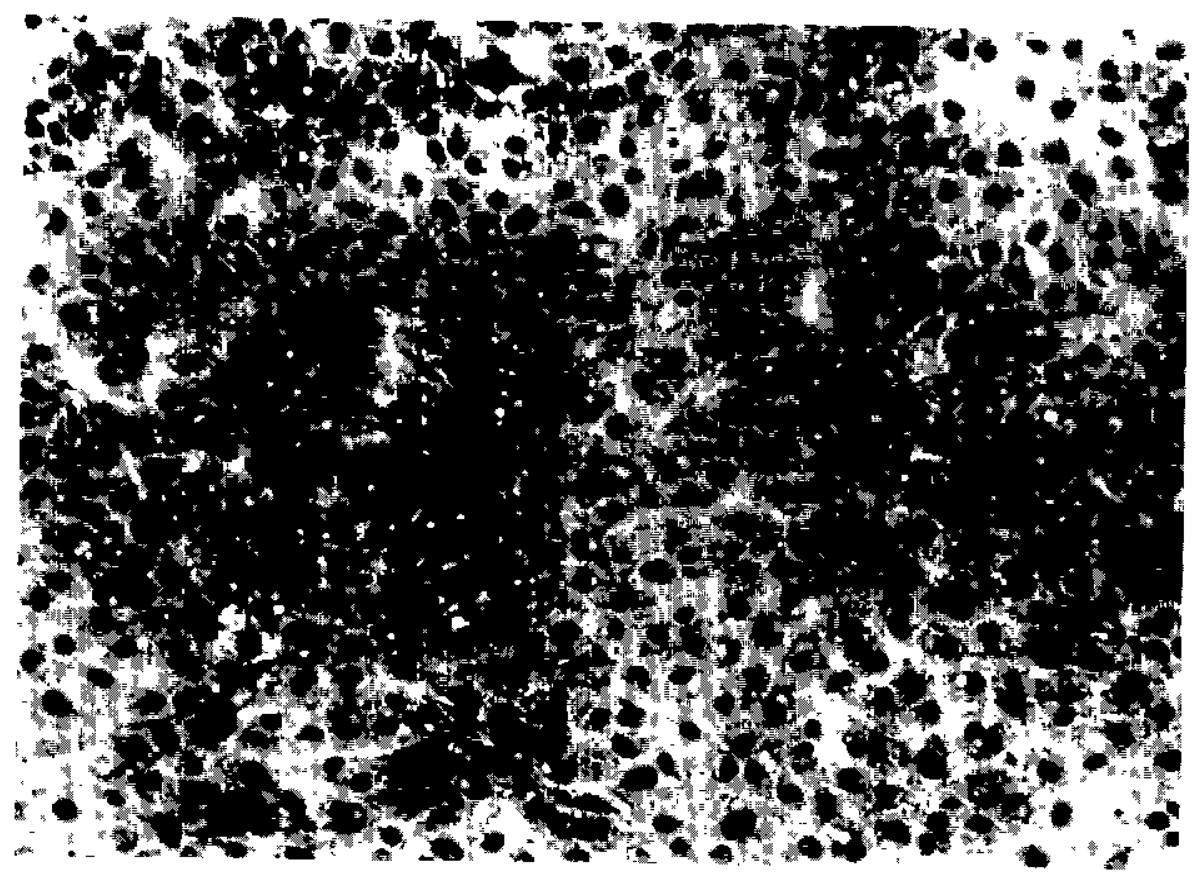

Photo 1. - Cellules testrculaires non inoculées.

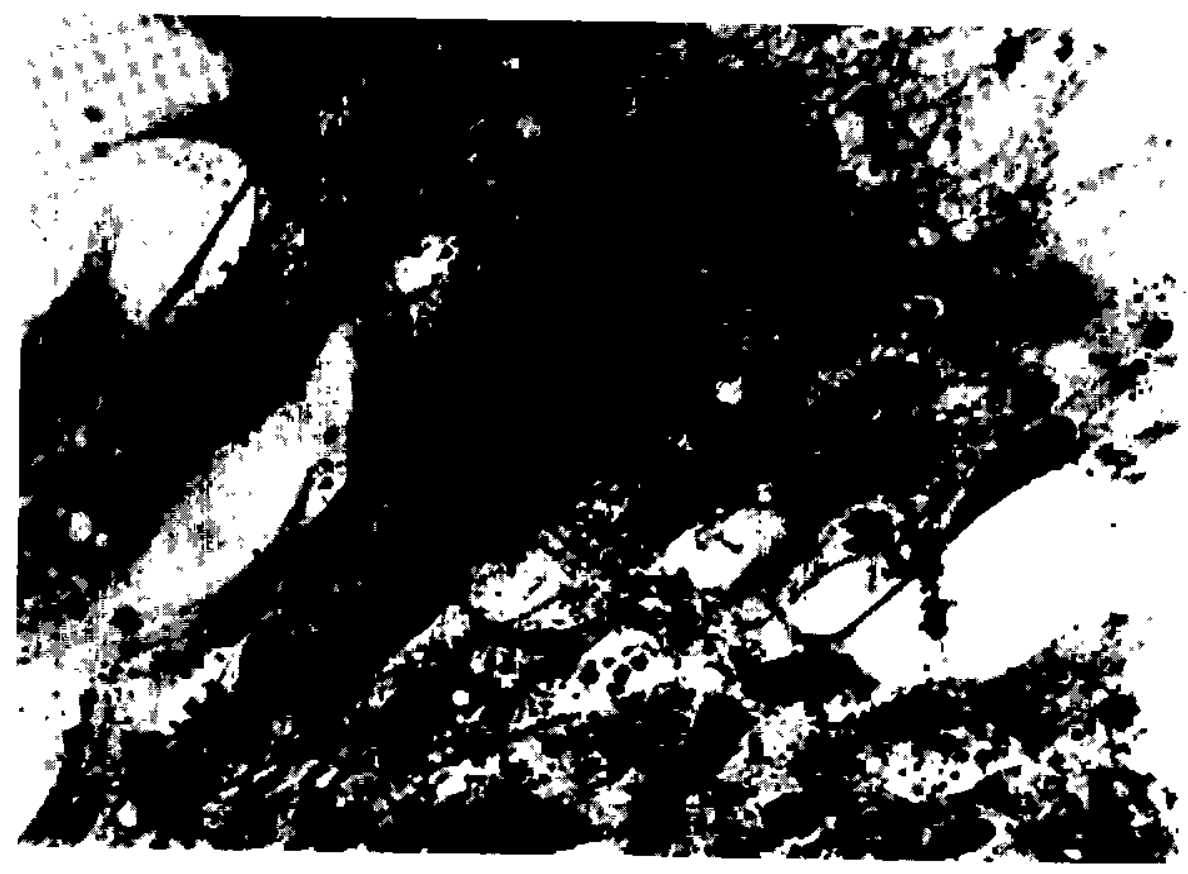

Photo 2. - Effet cytopathogène du virus de Newcistle sur cellules testiculaires préalablement infectées avec le virus sui-pestıque: Jyse cytoplasmique, plasmodes, inclusions. 


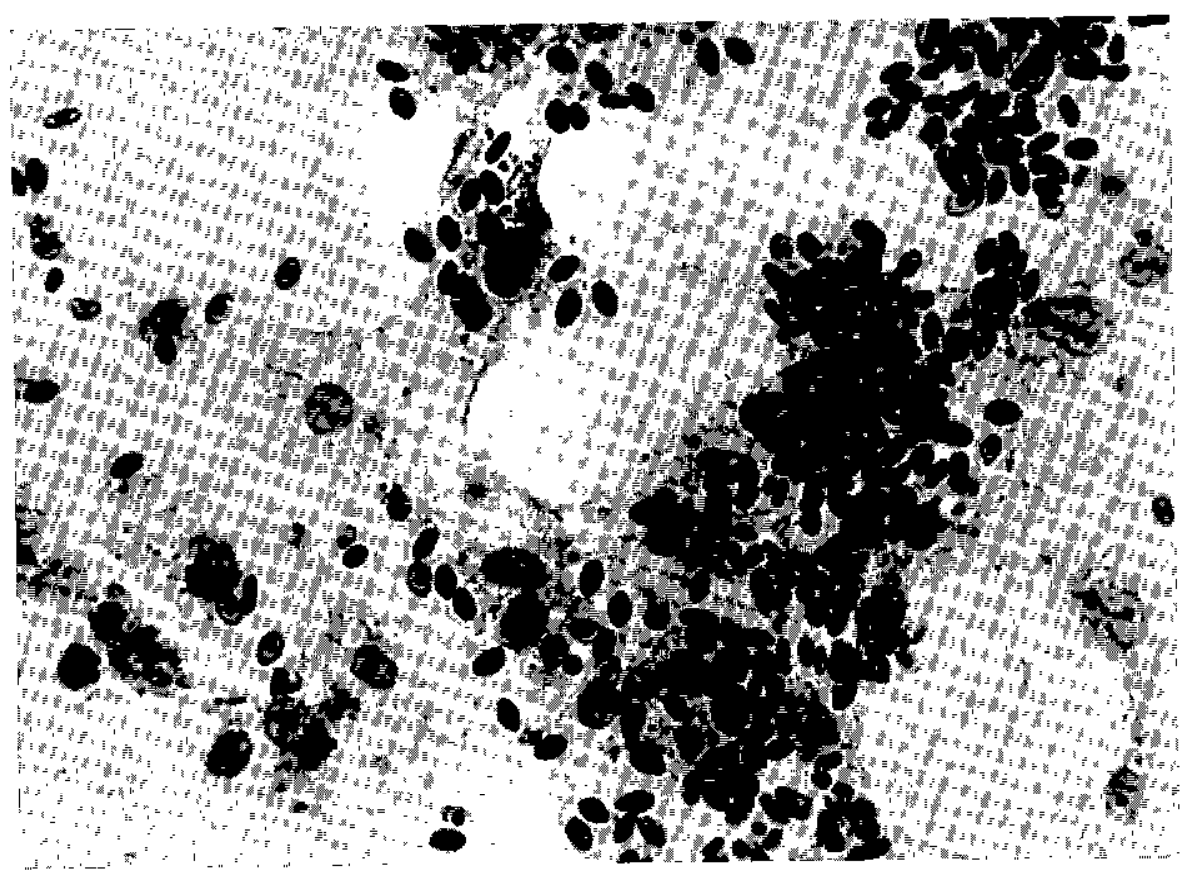

Photo 3. - Hémadsorption sur cellules testiculaires infectées de virus sui-pestique et surinfectées par le virus de Newcastle.

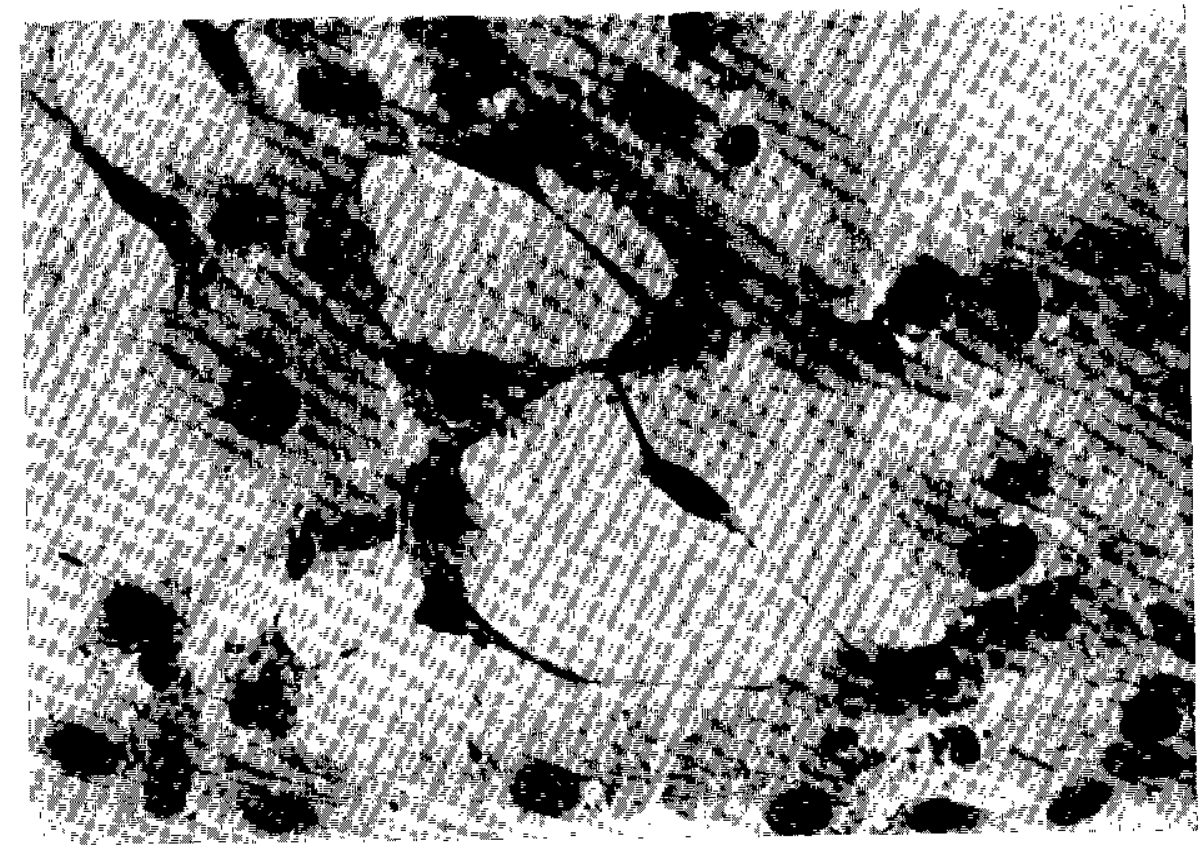

Photo 4. - Cellules testiculaires infectées de virus su1-pestıque et surinfectées de virus de Teschen. 
forment dans la nappe, car les cellules lysées se détachent du verre. La destruction cellulaire est totale en 48 ou 72 heures. Cet effet cytopathogène est représenté sur la photo $n^{\circ} 4$.

\section{Spécificité de la réaction}

Elle est démontrée par la présence de témoins et par la séro-neutralisation.

En fin d'observation, les cellules doivent être intactes dans tous les tubes témoins : témoin peste porcine, témoin organe non infecté, témoin milieu, témoin virus révélateur. Or les cellules des tubes témoins ne demeurent en bon état que si un certain nombre de conditions sont respectées. Ces conditions sont étudiées dans le chapitre suivant.

Par ailleurs le virus sui-pestique préalablement neutralisé par l'immunsérum n'est plus apte à sensibiliser les cellules testiculaires au virus de Newcastle. Nous l'avons montré en neutralisant avec un sérum commercial (dilué au $1 / 20$ et au $1 / 40$ ) du broyat de rate pesteuse contenant environ $10^{+} \mathrm{DIMCT} / \mathrm{ml}$, avant de l'inoculer aux cultures cellulaires. Une partie de ce broyat, non neutralisée, a servi de témoin d'infectiosité.

\section{Milieux les plus favorables à la réalisation du test}

Nous distinguerons les milieux les meilleurs pour la multiplication cellulaire, pour l'entretien des cellules pendant la replication du virus sui-pestique, et du virus surinfectant.

\section{Au $1^{e r}$ stade de la réaction: multiplication cellulaire}

La première condition pour la bonne réussite $\mathrm{du}$ test est que les cellules, au moment de l'inoculation sui-pestique, soient en excellent état. Il faut donc un milieu convenable pour la multiplication cellulaire (couche non granuleuse et complète en trois jours). De tous les milieux de base expérimentés, celui qui nous a donné les meilleurs résultats est celui comportant de l'hydrolysat de lactalbumine et de l'extrait de levure en solution de HANKS. Quant au sérum, il vaut mieux employer celui de veau (local ou importé), et à la concentration de 20 p. 100 . En effet les cellules apparaissent granuleuses et plus fragiles avec une concentration de 10 p. 100 , ou par l'emploi d'autres sérums (mouton).
Au $2^{e}$ stade: entretien des cellules pendant la replication du virus sui-pestique

A ce stade, il est indispensable que le milieu maintienne les cellules en bon état, et que le sérum ne soit pas inhibiteur pour le virus suipestique.

Pour conserver les cellules intactes pendant les quatre jours entre l'inoculation et la surinfection, nous renouvelons le milieu une fois (au $2^{\mathrm{e}}$ jour). De tous les milieux de base étudiés, c'est indiscutablement celui de SCHWÖBEL qui a le mieux maintenu les cellules en état. Pas de dégénérescence même en bordure de la nappe ou dans le fond des tubes. On note seulement des zones de condensation cellulaire où le tapis apparaît plus dense, ce qui correspond à des amas en plusieurs couches. Avec les autres milieux, les cellules deviennent granuleuses, fibroblastiques, se rétractent par endroits, et parfois sont partiellement lysées.

Concernant le sérum à incorporer dans le milieu, il faut le choisir en tenant compte de deux critères: il doit maintenir les cellules en état, et il ne doit pas être inhibiteur pour le virus sui-pestique. Compte tenu de ces deux exigences, nous avons choisi le sérum de mouton; il n'altère pas les cellules, et il n'empêche pas la replication du virus. Tous les lots de sérum de mouton que nous avons testés ont donné satisfaction. La concentration optimale est de 10 p. 100.

Par contre, les sérums de veau et de foetus bovin maintiennent bien les cellules, mais sont assez souvent inhibiteurs pour le virus. Les sérums de lapin et de porc, ainsi que le liquide amniotique bovin permettent la replication du virus sui-pestique, mais n'entretiennent pas les cellules en aussi bon état que les sérums de veau ou de mouton. Quant aux sérums de poule et de poulain, non seulement ils rendent les cellules très granuleuses et plus fragiles, mais en plus, ils semblent être inhibiteurs pour le virus.

Au $3^{4}$ stade: entretien des cellules après la surinfection

Il faut que le milieu maintienne les cellules témoins en bon état et n'entrave pas la multiplication du virus révélateur dans les cultures primo-infectées de virus sui-pestique.

Le milieu de SCHWÖBEL est encore le meilleur et il permet une lecture nette des 
résultats. Il empêche toute dégénérescence spontanée des cellules et la lyse par le seul virus de Newcastle. Il permet une survie prolongée, même sans renouvellement du milieu. Quant au sérum on peut prendre indifféremment celui de veau ou de mouton qui n'altèrent pas les cellules, et ne sont pas inhibiteurs pour le virus de Newcastle. Il vaut mieux, à notre avis, les incorporer à 10 p. 100 plutôt qu'à 20 p. 100 (taux préconisé par KUMAGAI) (6). Car la concentration à 20 p. 100 retarde l'effet cytopathogène et n'améliore pas, selon notrc expérimentation, l'état des cellules.

Les résultats des différents essais de milieux et de sêrums sont résumés dans le tableau $n^{\circ} 2$,

\section{Etude d'autres paramètres de la réaction}

\section{Influence de la rotation des tubes surinfectés}

La rotation des tubes après la surinfection raccourcit le délai d'apparition de l'effet cytopathogène, en général de 24 à 48 heures. La destruction de la nappe cellulaire est plus rapide et plus complète. Mais il peut arriver aussi, lorsque les cellules ne sont pas en parfait état au moment de la surinfection, que la rotation des tubes augmentant l'effet cytopathogène du virus surinfectant, provoque en même temps une lyse partielle dans les cultures témoins. La morphologie des cellules en voie de lyse

TABLEAU N $\mathbb{N}^{\circ} I I$

Milieux et sěrums expérimentés dans le test I.N.D.

\begin{tabular}{|c|c|c|c|c|c|c|}
\hline \multicolumn{2}{|c|}{ Milieux de cultures } & Stade 1 & \multicolumn{2}{|c|}{ stade 2} & \multicolumn{2}{|c|}{ Sta $\mathrm{a} e$} \\
\hline \multicolumn{2}{|c|}{ Milieux de base } & $\begin{array}{l}\text { Etat des } \\
\text { cellules }\end{array}$ & $\begin{array}{l}\text { Itat des } \\
\text { celiules }\end{array}$ & $\begin{array}{c}\text { Replication } \\
\text { virale }\end{array}$ & $\begin{array}{l}\text { Etat des } \\
\text { cellules }\end{array}$ & $\begin{array}{l}\text { Replication } \\
\text { virale }\end{array}$ \\
\hline \multicolumn{2}{|c|}{$\begin{array}{l}\text { Hydrolysat de lactalbumine } \\
+ \text { extrait de levure, sol } \\
\text { de HANKS }\end{array}$} & Excellent & Assez bon & Non démontrée & Médrocre & Non démontrée \\
\hline \multicolumn{2}{|c|}{$\begin{array}{l}\text { Hydrolysat de lactalbumine } \\
\text { sol. RARLE }\end{array}$} & Médiocre & Médiocre & Non démontrée & Médiocre & Non démontrée \\
\hline \multicolumn{2}{|c|}{$\begin{array}{l}\text { Hydrolysat de caséine } \\
+ \text { vit. B, sol. EARLE }\end{array}$} & Médiocre & Médiocre & Non démontrée & Assez bon & Possible \\
\hline \multicolumn{2}{|c|}{ Milieu B.E.M. de EAGLE } & Assez bon & Assez bon & Possible & Assez bon & Possible \\
\hline \multicolumn{2}{|c|}{ Milieu M.E.M. de EAGLE } & Mauvais & Mauvais & $\begin{array}{l}\text { Cellules en } \\
\text { voie de lyse }\end{array}$ & Mauveis & 0 \\
\hline \multicolumn{2}{|c|}{ Milieu 199} & Médiocre & Assez bon & Possible & Assez bon & Possible \\
\hline \multicolumn{2}{|c|}{ Milieu de SCHWOBEL } & Non essayé & Excellent & Bonne & Excellent & Bonne \\
\hline \multirow[t]{8}{*}{ Sérums de : } & Veau $10 \mathrm{p} \cdot 100$ & Moyen & Excellent & $\begin{array}{l}\text { Souvent inhi- } \\
\text { biteur }\end{array}$ & Excelient & Bonne \\
\hline & $20 \mathrm{p} \cdot 100$ & Excellent & Bon & \begin{tabular}{|l|} 
Souvent inhi- \\
biteur \\
\end{tabular} & Moyen & Retardée \\
\hline & Foetus bovin & Non essayé & Excellent & Inhibiteur? & Mon essayé & \\
\hline & Mouton 10 p. 100 & Granuleuses & Excellent & Bonne & Excellent & Bonne \\
\hline & Lapin & Non essayé & Médiocre & Posaible & Non essavé & \\
\hline & Porc & Granuleuses & Médiocre & Possible & Jon es\$ayé & \\
\hline & Poulain & Non essayé & Mediocre & Inhibiteur : & Non essayé & \\
\hline & Poule & Non essayé & Mediocre & Inhibiteur? & Non essayé & \\
\hline \multicolumn{2}{|c|}{ Liquide amnotique bovin } & Non essayé & Moyen & Possible & Non essayé & \\
\hline \multicolumn{2}{|c|}{ Lait écrémé } & Médiocre & Médioere & Non démontrée & Non essayé & \\
\hline
\end{tabular}


est un peu différente de celle que l'on observe sur tubes fixes. Il se forme des amas cellulaires à contours festonnés n'ayant pas du tout l'aspect effiloché et fibroblastique des cellules demeurant immobiles.

\section{Effet cytotoxique des inoculums trop concentrés}

Les suspensions tissulaires trop concentrées peuvent être toxiques pour les cellules. Les suspensions de rate, rein, cerveau le sont jusqu'au $1 / 5$ - celle de ganglions l'est jusqu'au $1 / 20$ - celle de pancréas l'est jusqu'au 1/80. Ces résultats concernent des cultures complètement développées en couche monocellulaire. Dans le cas de cellules inoculées à la mise en culture, les suspensions organiques doivent être notablement plus diluées.

\section{Dilution des virus - Gammes utilisables}

Pour le virus sui-pestique, nous avons examiné un certain nombre de rates infectées (souche A.L.D., souches locales). La moyenne des résultats montre que la souche A.L.D. est régulièrement active à la dilution $10^{-\overline{-}}$, et irrégulièrement à la dilution $10^{-1:}$. Quant aux souches locales, les dilutions limites sont de l'ordre de $10^{-2}, 10^{-3}$.

Pour le virus de Newcastle surinfectant, la dilution limite encore efficace est de l'ordre de $10^{-7}$, ce qui correspond à environ 10 DICT. En milieu de SCHWÖBEL, il faut une concentration de $10^{-1}$ pour que le virus de Newcastle, inoculé seul, lyse les cellules. La gamme convenable pour ce virus va donc de $10^{-2}$ à $10^{-7}$. Pour avoir une réponse assez rapide, nous utilisons dans les diagnostics courants les dilutions $10^{-3}$ ou $10^{-4}$ (soit $10^{-5}$ ou $10^{4}$ DICT).
Quant au virus de Teschen, s'il est trop concentré, il lyse les cellules, même en l'absence de virus sui-pestique. Pratiquement, pour éviter cette action indésirable, il faut le diluer à $10^{-5}$. La dilution limite encore efficace est de l'ordre de $10^{-7}$.

\section{Modification chronologique du test}

Les résultats sont présentés dans le tableau $n^{\circ} 3$.

D'après ce tableau, on pourrait conclure que la meilleure méthode est celle qui consiste à inoculer le virus sui-pestique, le lendemain de la mise en culture, et de surinfecter 2 jours plus tard. Il nous semble préférable de revenir à la technique classique parce que l'inoculation le lendemain de la mise en culture fragilise les cellules.

\section{Influence de la nature des souches}

a) Souches de peste porcine

- Souche A.L.D.: Les prélèvements conservés au congélateur $\left(-30^{\circ}\right)$ ont donné les résultats positifs suivants: sérums lyophilisés $5 / 5$, sérums congelés $15 / 29$, rates congelées $15 / 21$, rates lyophilisées $8 / 8$, sangs lyophilisés $4 / 4$. Certains prélèvements ayant subi plusieurs cycles de congélation - décongélation n'étaient. plus infectieux. Des sérums congelés depuis 2 ans l'étaient encore.

- Souches locales: Dans les prélèvements congelés ou glycérinés (cerveaux), nous avons mis en évidence le virus sui-pestique dans 14 rates sur 26,2 cerveaux sur 16,2 sérums sur 5,5 ganglions sur 7 .

TABLEAU $\mathrm{N}^{\circ}$ III

Modification chronologique

\begin{tabular}{|c|c|c|c|}
\hline $\begin{array}{l}\text { Mise en culture } \\
\text { des cellules }\end{array}$ & $\begin{array}{l}\text { Inoculation } \\
\text { sui pestique }\end{array}$ & $\begin{array}{l}\text { Inoculation } \\
\text { Newcastle }\end{array}$ & $\begin{array}{l}\text { Apparition de } \\
\text { I'E.C.F. }\end{array}$ \\
\hline Jour 0 & Jour 0 & Non faite & $\begin{array}{l}\text { Cellules lysées } \\
\text { le lenaemain }\end{array}$ \\
\hline Jour 0 & Jour 1 & Jour 3 & + su jour 7 \\
\hline Jour 0 & Jour 3 & Jour 0 & Négatif \\
\hline Jour 0 & Jour 3 & Jour 3 & \pm au jour 8 \\
\hline Jour 0 & Jour 7 & Jour 3 & Négatif \\
\hline Jour 0 & Jour 3 & Jour 7 & $\begin{array}{c}+ \text { au jour } 10 \\
\text { (test classique) }\end{array}$ \\
\hline
\end{tabular}


- Souches vaccinales: Aucune des 2 souches vaccinales utilisées (locale dérivée de la souche SFA, et IFFA) n'a donné de résultat positif au test E.N.D. dans notre expérimentation. Qu'il s'agisse de la souche obtenue sur lapin (rate de lapin), passée sur cellules rénales de lapin (vaccin IFFA) ou repassée sur porc (par vaccination). Ceci nous permet donc d'appliquer le test sans nous préoccuper d'une éventuelle vaccination antérieure.

\section{b) Souches Newcastle}

Toutes les souches examinées peuvent convenir, à lexception d'une (Toulouse), car elles donnent un résultat positif. Cependant deux lysent 24 heures plus tôt : ce sont la souche Pakistanaise vaccinale et la souche pathogène d'épreuve. Il ne semble pas que l'aptitude de ces souches à révéler le virus sui-pestique soit en rapport avec leur titre cytopathogène déterminé sur cellules $\mathrm{KB}$.

\section{DISCUSSION}

D'après nos propres résultats nous estimons que, pour l'exécution du test E.D.N., l'adoption comme milieu dentretien du milieu de SCHWÖBEL et du sérum de mouton (10 p. 100) résout les deux difficultés principales: maintien des cellules en bon état, non inhibition $\mathrm{du}$ virus sui-pestique.

Ainsi, n'est-il pas nécessaire d'augmenter le pourcentage de sérum à 20 p. 100 comme le recommandent KUBIN (3) et KUMAGAI (6). Il n'est pas nécessaire non plus de tester les sérums comme dans le cas du sérum de veau. Il est à noter que LOAN (7) avait retenu le sérum de chèvre, et que KUMAGAI (6) avait étudié le sérum de mouton à la concentration de 20 p. 100.

La modification de la chronologie du test ne nous a pas apporté de résultats appréciables. L'inoculation le lendemain de la mise en culture nous donne un résultat positif, de même qu'à LOAN (8), mais c'est aux dépens du bon état des cellules. L'inoculation simultanée, au moment où la nappe est complète, entraîne des résultats irréguliers (idem BOOL et RESSANG) (1). L'inoculation inversée est pour nous négative, alors qu'elle est parfois positive pour ces derniers auteurs.

En ce qui concerne les souches vaccinales, les deux que nous avons examinées donnent un résultat négatif. Alors que pour LOAN (8), certaines souches vaccinales positivent le test, et que pour BOOL et RESSANG (1), la souche IFFA le positive aussi.

\section{CONCLUSION}

Grâce à l'emploi du milieu de SCHWÖBEL et du sérum de mouton, nous pensons avoir amélioré la technique du test E.N.D. en diminuant la dégénérescence spontanée des cellules, ou l'action directe du virus surinfectant seul. Ainsi appliqué, le test E.N.D. nous a permis de mettre en évidence des souches sui-pestiques locales, aussi bien que la souche d'épreuve A.L.D. Les deux souches vaccinales lapinisées ont donné, dans les conditions de l'expérience, un résultat négatif. Il nous semble donc que ce test peut permettre le diagnostic de la peste porcine à Madagascar, sans avoir recours à l'inoculation du porc.

\footnotetext{
Institut d'Elevage et de Médecine Vétérinaire des Pays Tropicaux. Laboratoire Central de l’Elevage, Tananarive.
}

\section{SUMMARY}

\section{Researches on the experimental diagnosis of classical swine fever by the exaltation method of Newcastle virus}

The various factors conditioning the detecting of swine fever virus by the exaltation method of Newcastle virus, in cells culture, (E.N.D. test) are studied by the authors. They have employed as maintenance medium of cells, this of SCHWÖBEL enriched with swine serum $(10$ p. 100). The swine fever virus challenge strain and the local virulent strains give a positive result. The two lapinized virus strains give a negative result. The rotation of inoculed tubes accelerates the cytopathogenic process. The most of Newcastle strains used as revealing virus are suitable. The series of dilutions of revealing virus can have relatively wide intervals. Some too 
concentrated tissular suspensions cause the cell lysis. The suspected material can be inoculated before the cells layer is complete. But the inoculation, the first day of the cells seeding can cause the lysis of cells, or delay their development.

\section{RESUMEN}

\section{Investigaciones sobre el diagnóstico experimental de la peste porcina clásica por el método de exaltación del virus de Newcastle}

Los autores estudian varios factores condicionando el evidenciar del virus sui-pestico por el método de exaltación del virus de Newcastle, en cultivo celular (prueba E.N.D.). Escogieron como medio de conservación de las células el de SCHWoBEL enriquecido con suero de oveja (10 p. 100). La cepa sui-pestica de prueba y las cepas virulentas locales dan un resultado positivo. Las dos cepas lapinizadas estudiadas dan un resultado negativo. La rotación de los tubos inoculados acelera el proceso citopatogeno. Convienen la mayor parte de las cepas Newcastle utilizadas como virus revelador. La escala de diluciones del virus revelador puede ser relativamente extendida. Ciertas suspensiones tisulares demasiado concentradas provocan la lisis de las células. Es posible inocular el material sospechoso antes que la alacena celular sea completa. Pero la ínoculación el primer día de cultivo puede provocar la lisis de las células, o diferir su desarrollo.

\section{BIBLIOGRAPHIE}

1. BOOL (P. H.) et RESSANG (A. A.). 1966, «Varken pest diagnostick met behulp van de E.T.V. E.N.D. en de immunofluorescentietechnieken », Tijdschr. Diergenek 18, (91), 1148-1163.

2. KAADEN (O.R.) et WITTMANN (E.), 1968, "Critical observations on the suitability of the E.N.D, method for detecting swine fever virus in tissue culture », Vet. Bull. 38, (11), 4573 p. 782.

3. KUBIN (G.), 1962, «La culture du virus de la peste porcine en couche monocellulaire $»$, Trad. Bull. O.I.E. 57, (9-10), 1395-1406.

4. KUMAGAI (T.), SHIMIZU (T) et MATUMOTO (M.), 1958, « Detection of hog cholera virus by its effect on Newcastle disease virus in swine tissue culture $»$, Science. 128, 366.

5. KUMAGAI (T.), SHIMIZU (T.), IKEDA (S.) et MATUMOTO (M.), 1961, «A new in vitro method
(E.N.D.) for detection and measurement of hog cholera virus and its antibody by means of effect of hog cholera virus on Newcastle disease virus in swine tissue culture. I. Establishment of standard procedure $», J$. Immunol. 87, 245-256.

6. KUMAGAI (T.), SHIMIZU (T.), IKEDA (S.) et MATUMOTO (M.), 1964, « Technical improvment of the E N.D. method ", Arch. $f$. d. Ges. virtusfors. 14, (5), 697-699.

7. LOAN (R.W.) et McCAIN (C.S.), 1963, «Goat sera as media supplements in exaltation of Newcastle disease virus (E.N.D.) test for hog cholera virus », Proc. Book, 67th Ann. Meeting U.S. Livestock San. Ass. 348-357.

8. LOAN (R. W.), 1965, «Increased sensitivity of the E.N.D. (exaltation of Newcastle disease virus) test for hog cholera virus ", Am. J. vet. Res. 26, (114), 1110-1113. 